\title{
Factors Controlling Aldosterone Secretion during Hypoxemia in Fetal Lambs
}

\author{
JEAN E. ROBILLARD, (36) NANCY A. AYRES, \\ R. ARIEL GOMEZ, KENNETH T. NAKAMURA, AND FRED G. SMITH, JR. \\ Departments of Pediatrics and Internal Medicine and The Cardiovascular Research Center, University of Iowa \\ College of Medicine, Iowa City, Iowa, USA
}

\begin{abstract}
Summary
Factors modulating the fetal aldosterone response to hypoxemia were studied in three groups of chronically catheterized fetal lambs between 131 and 143 days of gestation (term, 145 days). One group (control group) received an infusion of $5 \%$ dextrose in water; the second group (captopril-treated group) was given captopril, an inhibitor of angiotensin-converting enzyme; the third group (captopril plus dexamethasone-treated group) received dexamethasone in addition to captopril. In all groups of fetuses, hypoxemia was associated with a significant increase in plasma $\mathrm{K}^{+}$concentration $(+0.7 \pm 0.1 \mathrm{meq} / \mathrm{liter})$. In control fetuses, changes in plasma aldosterone concentration during hypoxemia correlated closely with changes in plasma $\mathrm{K}^{+}$concentration $r=0.79 ; P<0.001)$ and with changes in plasma angiotensin II concentration $(r=0.77 ; P<0.001)$. In the captopril-treated fetuses, the rise in plasma aldosterone concentration during hypoxemia correlated closely with plasma $\mathrm{K}^{+}(r=0.79 ; P<0.001)$ but not with plasma angiotensin II values $(r=0.17)$. No significant correlation was found between percent changes in maternal aldosterone and percent changes in fetal aldosterone during hypoxemia and following recovery $(r=0.36 ; P>0.1)$ in captopriltreated fetuses. Administration of dexamethasone to fetuses receiving captopril completely inhibited the rise in plasma aldosterone associated with hypoxemia. Taken together, the present results suggest that the rise in plasma aldosterone during hypoxemia is not related to the level of activity of the renin-angiotensin system but depends probably on the increased secretion of adrenocorticotrophin by the fetus. It is also suggested that maternal placental transfer of aldosterone is not an important factor controlling the rise in fetal plasma aldosterone concentration during hypoxemia.
\end{abstract}

\section{Abbreviations}

A-II, angiotensin II

ACTH, adrenocorticotrophin

PRA, plasma renin activity

Much has been learned about the direct mediators governing aldosterone secretion in adult humans and experimental animals $(14,18)$. However, mechanisms regulating aldosterone secretion during fetal life are poorly understood. Previous in vitro studies $(3,8,20,32,33)$ have shown that the fetal adrenal gland has the ability to synthesize and secrete aldosterone following stimulation by either A-II (33), ACTH (33), or increasing potassium concentration (32). More recently, we $(21,22)$ and others (27) demonstrated that in vivo elevation of plasma A-II concentration stimulates aldosterone secretion during the last trimester of gestation in fetal lambs but to a lesser degree than in adult ewes
(22). However, in vivo attempts to stimulate aldosterone secretion by ACTH $(1,5)$ or potassium infusion $(31)$ have been unsuccessful, suggesting a relative insensitivity of the fetal adrenal to these stimuli.

On the other hand, we have found a close correlation between plasma aldosterone and plasma potassium concentrations in nephrectomized fetuses submitted to blood volume depletion (21). Similar findings have also been described by Dutton and Mott (9) in nephrectomized fetal lambs not submitted to hemorrhage, suggesting that under certain circumstances, changes in potassium concentration may regulate aldosterone secretion during fetal life.

In a previous study (24), we found that fetal hypoxemia, not accompanied with acidosis and/or hypercapnea, is associated with a significant rise in plasma potassium concentration and an increased activity in the renin-angiotensin system. However, there are no data available concerning the fetal adrenal response to hypoxemia and factors that may modulate this response. The present protocol was therefore designed to study the fetal adrenal response to hypoxemia in chronically catheterized fetal lambs. Moreover, the present study examined the mechanisms regulating aldosterone secretion during fetal hypoxemia. More specifically, we investigated the role of angiotensin II and ACTH in modulating aldosterone secretion during the endogenous elevation of plasma potassium concentration associated with fetal hypoxemia. Finally, the role of maternal plasma aldosterone concentration on the fetal adrenal response to hypoxemia was also investigated.

\section{MATERIALS AND METHODS}

Pregnant sheep of Dorset and Suffolk mixed breeding were obtained from a local source and gestational age was based on the induced ovulation technique as previously described (23). Prior to surgery, the animals were fasted for $48 \mathrm{~h}$. Anesthesia of the ewe and surgery of the fetus were performed as described previously (23). Briefly, under general anesthesia using a mixture of $1 \%$ halothane, $33 \%$ oxygen, and $66 \%$ nitrous oxide, catheters were inserted into the fetal femoral artery and vein and secured with silk ligatures. An additional catheter was also secured in the amniotic cavity for intrauterine pressure recording. Following surgery, the ewes were kept in a restricted area and fed a standard diet. All vascular catheters were impregnated with dimethyl polysiloxane (Accumetric, Elizabethtown, CT), to reduce clotting and were irrigated every other day with a heparinized solution. A recovery period of at least 6 days was required prior to performing experiments. Before the start of each experiment, fetal weight was estimated according to the following formula: fetal body weight $(\mathrm{kg})=[0.096 \cdot$ gestational age (days) $]-9.233$, $(r=0.85 ; P<0.001)(23)$. 
Physiological studies. Studies were performed in three different groups of chronically catheterized fetal lambs between 131 and 143 days gestation (term being 145 days). The first group of fetuses (control group; $n=10$ ) was given an infusion of $5 \%$ dextrose in water, used as vehicle for the captopril infusion, at a rate of $0.1 \mathrm{ml} / \mathrm{min}$. The second group (captopril-treated group; $n=7)$ received a constant infuson of captopril ( $d$-mercapto-2methylpropanoyl-L-proline; SQ 14225, Squibb and Sons, Princeton, $\mathrm{NJ}$ ) at a rate of $5 \mu \mathrm{g} / \mathrm{min} / \mathrm{kg}$ of body weight. The third group (captopril plus dexamethasone-treated group; $n=5$ ) was studied twice. In a first series of studies, captopril was infused as for the second group of fetuses. Three days later, the same experiment was repeated but dexamethasone $(0.5 \mathrm{mg}$ to fetuses and $5 \mathrm{mg}$ to ewes) was given at 12 and $2 \mathrm{~h}$ before starting the captopril infusion.

In order to assess that the amount of captopril was adequate, a bolus $(1 \mu \mathrm{g})$ of A-I was given intravenously before and $60 \mathrm{~min}$ after starting the captopril infusion. Before starting the infusion of captopril, administration of an A-I bolus increased arterial blood pressure by $26 \pm 2.3 \%$. Sixty minutes after starting the infusion of captopril, a second bolus of A-I increased arterial blood pressure by only $2.5 \pm 1.4 \%$, thereby showing a significant inhibition $(P<0.001)$ in the conversion of A-I to A-II.

Therefore, following a 60 -min equilibration period, a prehypoxemic arterial blood sample was taken for determination of $\mathrm{pH}$, blood gases $\left(\mathrm{PCO}_{2}, \mathrm{PO}_{2}\right)$, and plasma electrolytes $\left(\mathrm{Na}^{+}, \mathrm{K}^{+}\right.$, $\left.\mathrm{Cl}^{-}\right)$and for assay of PRA, A-II, aldosterone, and cortisol. Thereafter, fetal hypoxemia was induced by placing a bag over the ewe's head and forcing her to breathe a mixture of $11.1 \%$ oxygen and $88.9 \%$ nitrogen. The oxygen-nitrogen gas mixture was precalibrated at an accuracy level of $0.11 \%$ by Air Products Co., PA. Thirty minutes after initiation of hypoxemia, an hypoxemic arterial blood sample was taken. At the end of the hypoxemia period, the bag was removed and, after allowing the fetus to recover for $120 \mathrm{~min}$, a posthypoxemic arterial blood sample was taken. To prevent any hemodynamic effect of sampling, fetal blood was replaced with an equal amount of maternal blood after each fetal sample taken.

During each experiment, arterial and amniotic pressures were recorded continuously in every fetus using Statham $\mathrm{P} 23 \mathrm{Db}$ pressure transducers (Statham Instruments Division, Gould Inc.) and a Beckman R611 recorder. Fetal arterial blood pressures were corrected relative to concomitant amniotic pressure. Heart rate was monitored with a cardiotachometer triggered from the fetal arterial pressure pulse waves.

Analytical procedures. Blood for $\mathrm{pH}, \mathrm{PCO}_{2}$, and $\mathrm{PO}_{2}$ was collected anaerobically in heparinized glass syringes and measurements were immediately determined with the appropriate $\mathrm{pH}$, $\mathrm{PCO}_{2}$, and $\mathrm{PO}_{2}$ electrodes at $39^{\circ} \mathrm{C}$ using a Radiometer PHM 72 MK2 acid-base analyzer (Radiometer Co., Denmark). Plasma concentrations of sodium and potassium were determined by flame photometry using lithium as an internal standard and chloride by potentiometric titration (Radiometer CMT10-chloride titrator).

Blood samples for PRA measurements were collected in chilled tubes containing EDTA, and blood samples for cortisol and aldosterone determinations were collected in heparinized syringes. All samples were kept on ice and centrifuged within minutes at $4^{\circ} \mathrm{C}$. PRA and plasma aldosterone concentrations were determined by radioimmunoassays as previously described $(13,15)$. Plasma cortisol concentration was determined by radioimmunoassays (10) using a commercially available kit (Direct Cortisol Kit, Diagnostic Products Co.).

Blood samples for plasma A-II determinations were collected in chilled tubes containing $0.3 \mathrm{M}$ EDTA and $0.025 \mathrm{M} o$-phenanthroline. Thereafter, the cells and proteins were immediately precipitated with acetone $(65 \%)$ and the supernatant was dried under air for subsequent chromatographic isolation of A-II on SP-Sephadex in sodium acetate buffer. A-II was then measured by radioimmunoassay using the method previously described by
Cain et al. (6). The technique, reliability, and full characterization of this assay in our laboratory have been reported recently (22).

Statistical analysis. Statistical analysis of the data inside any given population of animals was performed by using Student's paired $t$ test. The unpaired $t$ test was used to compare the means between two different populations of animals. When multiple comparisons were done on the same group of data, the critical value of $t$ was corrected using the Bonferroni method (29). Regression lines and associated correlation coefficients were computed by the least squares formula. The term "significant" is used throughout the paper to describe changes with a total $P$ value of less than 0.05 in a two-sided significance limit. The results are presented as mean \pm standard error.

\section{RESULTS}

Effects of converting enzyme inhibition on fetal aldosterone response to hypoxemia. The effects of hypoxemia on arterial blood gases and plasma electrolyte concentration in both control and captopril-treated fetuses are presented in Table 1. Hypoxemia was associated with a significant decrease in $\mathrm{PCO}_{2}$ and a significant increase in plasma $\mathrm{K}^{+}$concentration in both control and captopril-treated fetuses; these changes were similar in both groups of fetuses. The arterial blood $\mathrm{pH}$ did not change significantly during hypoxemia but decreased significantly during the recovery period. These changes in blood $\mathrm{pH}$ corresponded to a return from hyperventilation to normal breathing by the ewe.

The effects of hypoxemia on PRA, plasma A-II, and plasma aldosterone concentration are presented in Table 2. Hypoxemia produced significant rises in PRA, plasma A-II, and plasma aldosterone concentrations in the control group. Inhibition of converting enzyme activity by captopril (captopril-treated group) blocked the A-II response to hypoxemia but did not interfere with the rise in PRA or with the increase in plasma aldosterone. The percent changes in plasma aldosterone concentration were similar in both control $(74.4 \pm 12.9 \%)$ and captopril-treated $(74.5 \pm 13.5 \%)$ fetuses during hypoxemia.

In the control group, changes in plasma aldosterone $(\mathrm{pg} / \mathrm{ml})$ during hypoxemia and recovery correlated closely with changes in plasma $\mathrm{K}^{+}(\mathrm{meq} / \mathrm{liter})(r=0.79 ; P<0.001)$ and in plasma AII concentrations $(\mathrm{pg} / \mathrm{ml})(r=0.77 ; P<0.001)$. Multiple regression analysis between these variables did not permit separating the influence of $\mathrm{K}^{+}$from A-II on changes observed in plasma aldosterone values; the partial correlations of coefficients were, respectively, 0.59 between aldosterone and $\mathrm{K}^{+}$and 0.54 between aldosterone and A-II.

In captopril-treated fetuses, plasma aldosterone concentration before, during, and following hypoxemia correlated closely with plasma $\mathrm{K}^{+}$levels $(r=0.79 \mathrm{P}<0.001)$ (Fig. 1) but not with plasma A-II values $(r=0.17)$. Similarly, when changes in plasma aldosterone concentration during and following hypoxemia were compared to changes in plasma $\mathrm{K}^{+}$levels, a very close correlation was observed $(r=0.94 ; P<0.001)$. No such correlation was found when changes in plasma aldosterone were compared to changes in plasma A-II values $(r=0.08)$.

The rise in fetal plasma aldosterone concentration during hypoxemia was not dependent on maternal placental transfer of aldosterone. No significant correlation was found between percent changes in maternal aldosterone and percent changes in fetal aldosterone during hypoxemia and following recovery $(r=$ $0.36 ; P>0.1$ ) in the captopril-treated fetuses. Moreover, multiple regression analysis between fetal plasma aldosterone, fetal plasma $\mathrm{K}^{+}$, and maternal plasma aldosterone concentrations demonstrated a high partial coefficient of correlation between fetal $\mathrm{K}^{+}$ and aldosterone values $(r=0.92)$ and a low partial correlation between fetal aldosterone and maternal aldosterone concentrations $(r=0.10)$.

Effects of converting enzyme inhibition and dexamethasone on fetal aldosterone response to hypoxemia. In an effort to determine if a rise in ACTH secretion during hypoxemia might have 
Table 1. Effect of hypoxemia on arterial blood values in fetal lambs nonexposed (control) or exposed to captopril (captopril-treated)

\begin{tabular}{|c|c|c|c|c|c|c|}
\hline & \multicolumn{3}{|c|}{ Control $(n=10)$} & \multicolumn{3}{|c|}{ Captopril-treated $(n=7)$} \\
\hline & $\mathrm{C}$ & $\mathrm{H}$ & $\mathrm{R}$ & $\mathrm{C}$ & $\mathrm{H}$ & $\mathrm{R}$ \\
\hline $\mathrm{pH}$ & $7.37 \pm 0.01$ & $7.35 \pm 0.02$ & $7.33 \pm 0.01^{*}$ & $7.38 \pm 0.01$ & $7.39 \pm 0.01$ & $7.34 \pm 0.02 *$ \\
\hline $\mathrm{PCO}_{2}(\mathrm{~mm} \mathrm{Hg})$ & $48 \pm 2$ & $42 \pm 2^{*}$ & $45 \pm 1$ & $45 \pm 2$ & $38 \pm 2^{*}$ & $44 \pm 3$ \\
\hline $\mathrm{PO}_{2}(\mathrm{~mm} \mathrm{Hg})$ & $24 \pm 2$ & $14 \pm 1^{*}$ & $24 \pm 2$ & $27 \pm 1$ & $15 \pm 1^{*}$ & $24 \pm 2$ \\
\hline $\mathrm{Na}^{+}$(meq/liter) & $145 \pm 1$ & $145 \pm 1$ & $144 \pm 1$ & $145 \pm 1$ & $144 \pm 1$ & $144 \pm 1$ \\
\hline $\mathrm{K}^{+}$(meq/liter) & $4.5 \pm 0.1$ & $5.1 \pm 0.2^{*}$ & $4.3 \pm 0.1$ & $4.6 \pm 0.2$ & $5.0 \pm 0.2^{*}$ & $4.5 \pm 0.1$ \\
\hline $\mathrm{Cl}^{-}$(meq/liter) & $102 \pm 2$ & $103 \pm 2$ & $103 \pm 2$ & $104 \pm 1$ & $104 \pm 1$ & $102 \pm 1$ \\
\hline
\end{tabular}

* For $P<0.05$ when hypoxemia $(\mathrm{H})$ or recovery $(\mathrm{R})$ values are compared to control values $(\mathrm{C}) . n$, number of animals. Values are means $\pm \mathrm{SEM}$.

Table 2. Effect of hypoxemia on the renin-angiotensin-aldosterone system in fetal lambs nonexposed (control) and exposed to captopril (captopril-treated)

\begin{tabular}{|c|c|c|c|c|c|c|c|c|}
\hline & \multicolumn{4}{|c|}{ Control } & \multicolumn{4}{|c|}{ Captopril-treated } \\
\hline & $n$ & $\mathrm{C}$ & $\mathrm{H}$ & $\mathrm{R}$ & $n$ & $\mathrm{C}$ & $\mathrm{H}$ & $\mathrm{R}$ \\
\hline PRA (ng/ml/h) & 10 & $13.1 \pm 3.7$ & $23.7 \pm 8.2^{*}$ & $7.8 \pm 2.4$ & 7 & $27.7 \pm 8.5$ & $41.2 \pm 13.4^{*}$ & $15.5 \pm 2.9$ \\
\hline A-II $(\mathrm{pg} / \mathrm{ml})$ & 10 & $51 \pm 8$ & $81 \pm 18^{*}$ & $41 \pm 5$ & 7 & $20 \pm 2$ & $22 \pm 3$ & $21 \pm 2$ \\
\hline Aldosterone $(\mathrm{pg} / \mathrm{ml})$ & 6 & $58 \pm 10$ & $97 \pm 16^{*}$ & $82 \pm 8^{*}$ & 7 & $43 \pm 3$ & $71 \pm 9^{*}$ & $48 \pm 10$ \\
\hline
\end{tabular}

* For $P<0.05$ when hypoxemia $(\mathrm{H})$ or recovery $(\mathrm{R})$ values are compared to control $(\mathrm{C})$ values. $n$, number of animals. Values are means $\pm \mathrm{SEM}$.

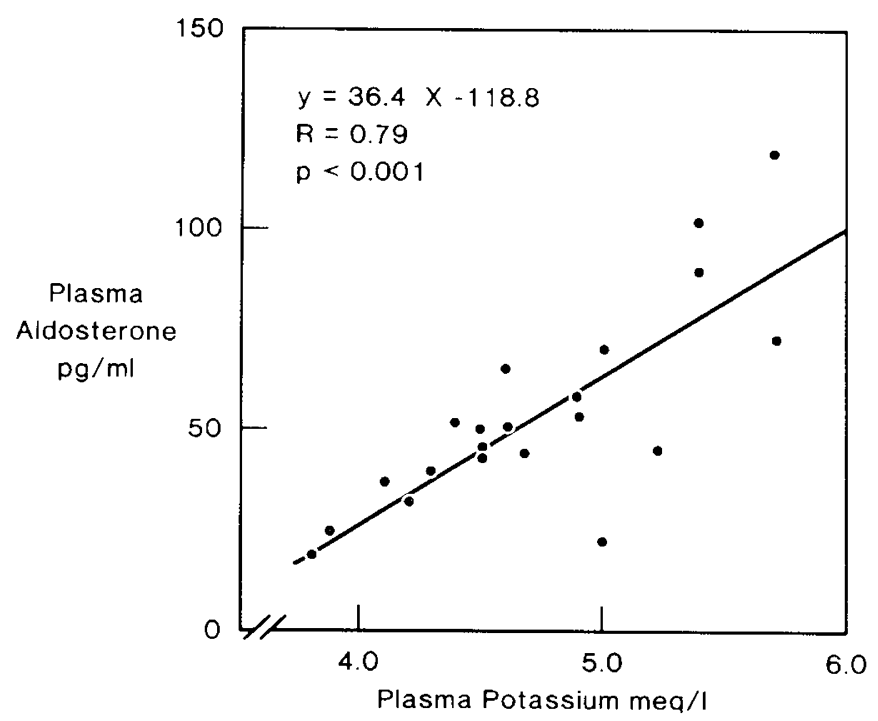

Fig. 1. Relationship between plasma potassium and plasma aldosterone concentrations during captopril infusion in fetal lambs submitted to hypoxemia.

contributed to the increase in aldosterone secretion during converting enzyme inhibition (captopril-treated fetuses), we studied a third group of fetuses in which ACTH secretion was suppressed by dexamethasone before starting the captopril infusion. Arterial blood values during captopril infusion in untreated and dexamethasone-treated fetuses are presented in Table 3. Arterial pH, blood gases $\left(\mathrm{PO}_{2}\right.$ and $\mathrm{PCO}_{2}$ ) and plasma electrolytes concentrations before, during, and following hypoxemia were similar in both untreated and dexamethasone-treated fetuses receiving captopril.

The effects of hypoxemia on plasma A-II, plasma aldosterone, and plasma cortisol concentrations during captopril infusion in dexamethasone-treated and untreated fetuses are presented in Table 4. As shown previously in captopril-treated fetuses (Table 2), captopril infusion completely inhibited the rise in plasma AIl concentration during hypoxemia and did not alter the aldosterone response to hypoxemia (Table 4). On the other hand, administration of dexamethasone completely blocked the rise in plasma aldosterone concentration during hypoxemia in fetuses receiving captopril. Moreover, dexamethasone blocked the rise in plasma cortisol concentrations seen during hypoxemia in captopril-treated fetuses (Table 4).

\section{DISCUSSION}

The present study demonstrates that plasma aldosterone concentration increases significantly during hypoxemia in fetal lambs. These findings support a previous study by our group (21) showing that the fetal adrenal gland has the ability to increase aldosterone secretion following stressful conditions such as hemorrhage. However, contrary to this study (21) where the rise in plasma aldosterone was significantly smaller following bilateral nephrectomy, the present study demonstrates that the rise in plasma aldosterone concentration during hypoxemia remains at the same magnitude following inhibition of A-II synthesis by captopril. Therefore, the present results suggest that the integrity of the renin-angiotensin system is not an important component in the adrenal response to hypoxemia but that factors other than A-II are modulating this response.

Previous attempts to study factors regulating aldosterone secretion during fetal life have shown that an increase in plasma potassium concentration (31) or ACTH infusion (4) cannot induce a significant rise in fetal plasma aldosterone concentration. On the other hand, the present study demonstrates that the rise in plasma aldosterone concentration during inhibition of AII synthesis correlates closely with the rise in plasma $\mathrm{K}^{+}$concentration, suggesting that $\mathrm{K}^{+}$may be an important factor modulating this response. Previous studies in anephric humans (7) and in nephrectomized animals (19) have shown that $\mathrm{K}^{+}$can stimulate aldosterone secretion in the absence of the renin-angiotensin system. However, the present results tend to differ from a previous study by Wintour et al. (31), who were unable to demonstrate a rise in fetal plasma aldosterone following an increase in plasma $\mathrm{K}^{+}$concentration. The differences in results between this study (31) and the present study cannot be attributed to different levels of $\mathrm{K}^{+}$stimulation since the rise in plasma $\mathrm{K}^{+}$concentration in both studies is similar. Furthermore, there is no evidence that the rise in plasma aldosterone during fetal hypoxemia originates from the mother by transplacental passage. It has been previously suggested that plasma aldosterone concentration in fetal lambs is maintained via placental transfer from the ewe $(25,26,28)$. However, no correlation is found in the present study between percent changes in fetal plasma aldosterone and maternal plasma aldosterone concentrations during hypoxemia and following recovery. Thus, the present results suggest that maternal placental 
Table 3. Effect of hypoxemia on arterial blood values during converting enzyme inhibition in dexamethasone-treated and untreated fetal lambs

\begin{tabular}{|c|c|c|c|c|c|c|}
\hline & \multicolumn{3}{|c|}{ Captopril $(n=5)$} & \multicolumn{3}{|c|}{ Captopril + dexamethasone $(n=5)$} \\
\hline & $\mathrm{C}$ & $\mathrm{H}$ & $\mathrm{R}$ & $\mathrm{C}$ & $\mathrm{H}$ & $\mathrm{R}$ \\
\hline $\mathrm{pH}$ & $7.33 \pm 0.01$ & $7.30 \pm 0.02$ & $7.33 \pm 0.02$ & $7.31 \pm 0.02$ & $7.28 \pm 0.03^{*}$ & $7.30 \pm 0.10$ \\
\hline $\mathrm{pCO}_{2}(\mathrm{~mm} \mathrm{Hg})$ & $48 \pm 1$ & $40 \pm 1^{*}$ & $47 \pm 2$ & $47 \pm 2$ & $43 \pm 2$ & $45 \pm 4$ \\
\hline $\mathrm{PO}_{2}(\mathrm{~mm} \mathrm{Hg})$ & $23 \pm 1$ & $13 \pm 1^{*}$ & $19 \pm 4$ & $21 \pm 3$ & $13 \pm 1$ & $21 \pm 4$ \\
\hline $\mathrm{Na}^{+}$(meq/liter) & $144 \pm 1$ & $144 \pm 1$ & $144 \pm 1$ & $145 \pm 1$ & $144 \pm 1$ & $143 \pm 1$ \\
\hline $\mathrm{K}^{+}(\mathrm{meq} / \mathrm{liter})$ & $4.1 \pm 0.2$ & $4.9 \pm 0.2^{*}$ & $4.0 \pm 0.1$ & $4.0 \pm 0.2$ & $4.9 \pm 0.2^{*}$ & $4.2 \pm 0.1$ \\
\hline $\mathrm{Cl}^{-}$(meq/liter) & $105 \pm 2$ & $104 \pm 2$ & $101 \pm 1$ & $102 \pm 2$ & $104 \pm 3$ & $101 \pm 4$ \\
\hline
\end{tabular}

* For $P<0.05$ when hypoxemia $(\mathrm{H})$ or recovery $(\mathrm{R})$ values are compared to control $(\mathrm{C})$ values. $n$, number of animals. Values are means $\pm \mathrm{SEM}$.

Table 4. Effect of hypoxemia on plasma A-II, aldosterone, and cortisol concentrations during converting enzyme inhibition in dexamethasone-treated and untreated fetal lambs

\begin{tabular}{|c|c|c|c|c|c|c|}
\hline & \multicolumn{3}{|c|}{ Captopril $(n=5)$} & \multicolumn{3}{|c|}{ Captopril + dexamethasone $(n=5)$} \\
\hline & $\mathrm{C}$ & $\mathrm{H}$ & $\mathrm{R}$ & $\mathrm{C}$ & $\mathrm{H}$ & $\mathrm{R}$ \\
\hline $\mathrm{A}-\mathrm{II}(\mathrm{pg} / \mathrm{ml})$ & $50 \pm 4$ & $53 \pm 8$ & $53 \pm 6$ & $58 \pm 12$ & $46 \pm 6$ & $49 \pm 6$ \\
\hline Aldosterone $(\mathrm{pg} / \mathrm{ml})$ & $38 \pm 8$ & $50 \pm 13^{*}$ & $43 \pm 11$ & $27 \pm 6$ & $24 \pm 7$ & $29 \pm 6$ \\
\hline Cortisol $(\mu \mathrm{g} / \mathrm{dl})$ & $4.12 \pm 1.00$ & $5.09 \pm 1.12 *$ & $3.87 \pm 1.41$ & $1.78 \pm 0.72$ & $1.58 \pm 0.61$ & $2.15 \pm 0.98$ \\
\hline
\end{tabular}

* For $P<0.05$ when hypoxemia $(\mathrm{H})$ or recovery $(\mathrm{R})$ values are compared to control $(\mathrm{C})$ values. $n$, number of animals. Values are means \pm SEM.

transfer is not an important factor in explaining the fetal plasma aldosterone fluctuations during hypoxemia. Moreover, the present study agrees with previous data demonstrating that over $80 \%$ of the aldosterone present in fetal blood is of fetal origin (34), and that the fetus itself has the ability to raise plasma aldosterone concentration in response to stressful conditions (21).

In an effort to further investigate the role of $\mathrm{K}^{+}$in stimulating aldosterone secretion, we tried to determine if a rise in plasma ACTH concentration may contribute to the increase in plasma aldosterone concentration during fetal hypoxemia. Previous studies in acute (2) and chronically catheterized fetal lambs (4, $16,17)$ have shown that hypoxemia is associated with a rise in plasma ACTH concentration. Using dexamethasone to suppress ACTH secretion, the present study demonstrated that baseline plasma cortisol concentrations decrease significantly and that the small but significant rise in plasma cortisol associated with fetal hypoxemia is blunted completely (Table 4). Moreover, despite a significant increase in plasma potassium concentration, it is observed in captopril-treated fetuses that the rise in plasma aldosterone concentration associated with hypoxemia is completely inhibited by dexamethasone.

Taken together, the present results tend to support the hypothesis that the rise in ACTH secretion associated with hypoxemia is an important factor in modulating aldosterone secretion. Moreover, the present study suggests that potasssium does not play a primary role in controlling aldosterone secretion during fetal hypoxemia and supports previous findings $(31,32)$ demonstrating that elevation of plasma potassium concentration alone does not produce significant increases in fetal plasma aldosterone concentration.

Possibilities still remain, however, that the present rise in plasma aldosterone concentrations represents synergism of potassium with ACTH during fetal hypoxemia. In favor of this hypothesis, it has been demonstrated in adults that potassium, independent of sodium and angiotensin, can sensitize the adrenal response to the aldosterone-stimulatory properties of ACTH (11, 30). Such an interaction may be necessary to stimulate aldosterone secretion during fetal life and may explain why ACTH infusion alone does not consistently stimulate aldosterone secretion in near-term fetuses $(1,5)$. Finally, since hypoxemia produces a rise in PRA and this rise is even greater during converting enzyme inhibition, it is possible that renin increases the sensitivity of the adrenal cortical response to the combined stimulation of potassium and ACTH during fetal life. Previous studies by Ganong et al. (12) have demonstrated that renin infusions in- crease the adrenocortical sensitivity to ACTH in adult dogs. However, the present study was not designed to investigate this aspect.

In summary, the present study demonstrates 1) that fetal plasma aldosterone concentration increases during hypoxemia. It is also shown that 2) that the rise in plasma aldosterone during hypoxemia is not related to the level of activity of the reninangiotensin system but depends probably on the increased secretion of ACTH by the fetus. 3) It is demonstrated that small increases of potassium within the physiologic range are not a predominant factor in modulating aldosterone secretion. However, it remains possible that potassium may potentiate the action of ACTH on the fetal adrenal gland. Finally, it is suggested 4) that maternal placental transfer of aldosterone is not an important factor controlling the rise in fetal plasma aldosterone concentration during hypoxemia.

\section{REFERENCES AND NOTES}

1. Alexander DP, Britton HG, James VHT, Nixon DA, Parker RA, Wintour EM, Wright RD 1968 Steroid secretion by the adrenal gland of foetal and neonatal sheep. J Endocrinol 40:1

2. Alexander DP, Forsling M, Martin JJ, Nixon DA, Ratcliffe JG, Redstone D, Tunbridge D 1972 The effect of maternal hypoxia on fetal pituitary hormone release in the sheep. Biol Neonate 21:219

3. Bloch $\mathrm{E}$, Benirschke K 1963 Steroidogenic capacity in foetal adrenals in vitro. In: Currie AR, Symington T, Grant JK (eds): The Human Adrenal Cortex. Edinburgh, E and S Livingstone Ltd, pp 589-595

4. Boddy K, Jones CT, Mantell C, Ratcliffe JG, Robinson JS 1974 Changes in plasma ACTH and corticosteroid of the maternal and fetal sheep during hypoxia. Endocrinology 94:588

5. Brown EH, Coghlan JP. Hardy KJ, Wintour EM 1978 Aldosterone, corticosterone, cortisol, 11 -deoxycortisol and 11 -deoxycorticosterone concentrations in the blood of chronically cannulated ovine foetuses: effect of ACTH. Acta Endocrinol 88:364

6. Cain MD, Coghlan JP, Catt KJ 1972 Measurement of angiotensin II in blood by radioimmunoassay. Clin Chem Acta 39:21

7. Cooke CR, Horvath JS, Moore MA, Bledsoe T, Walker WG 1973 Modulation of plasma aldosterone concentration by plasma potassium in anephric man in the absence of a change in potassium balance. $J$ Clin Invest 52:3028

8. Dufau ML, Villee DB 1969 Aldosterone biosynthesis by human fetal adrenal in vitro. Biochim Biophys Acta 176:637

9. Dutton A, Mott JC 1980 Plasma aldosterone measurements in intact and nephrectomized fetal lambs. J Physiol 307:81P

10. Farner RW, Pierce CE 1974 Plasma cortisol determination: radioimmunoassay and competitive protein binding compared. Clin Chem 20:411

11. Fredlund P, Saltman S, Kondo T, Douglas J, Catt KJ 1977 Aldosterone production by isolated glomerulosa cells: modulation of sensitivity to angiotensin II and ACTH by extracellular potassium concentration. Endocrinology 100:481

12. Ganong WF, Boryczka AT, Shackelford R 1967 Effect of renin on adrenocortical sensitivity to ACTH and angiotensin II in dogs. Endocrinology 80:703 
13. Haber ET, Koerner T, Page LB, Kliman B, Parnobe AJ 1969 Application of radioimmunoassay for angiotensin $\mathbf{I}$ to the physiologic measurements of plasma renin activity in normal human subjects. $J$ Clin Endocrinol Metab 29:1349

14. Hollenberg NK, Williams GH, Burger B, Hooshmand I 1975 The influence of potassium on the renal vasculature and the adrenal gland, and their responsiveness to angiotensin II in normal man. Clin Sci Mol Med 49:527

15. Ito T, Woo J, Haning R, Horton R 1972 A radioimmunoassay for aldosterone in human peripheral plasma including a comparison of alternate techniques. J Clin Endocrinol Metab 34:106

16. Jones CT, Ritchie JWK 1976 Endocrine and metabolic changes associated with periods of spontaneous hypoxia in fetal sheep. Biol Neonate 29:286

17. Jones CT, Ritchie JWK 1977 Corticosteroid inhibition of adrenocorticotrophin secretion in the foetal sheep. J Endocrinol 72:245

18. Laragh JH, Sealey JE 1973 The renin-angiotensin-aldosterone hormonal system and regulation of sodium, potassium and blood pressure homeostasis In: Orloff J, Berliner RW (eds): Handbook of Physiology. Washington, DC, American Physiological Society, pp 831-908

19. McCaa RE, McCaa CS, Cowley AW, Ott CE, Guyton AC 1972 Stimulation of aldosterone secretion by hemorrhage in dogs after nephrectomy and decapitation. Circ Res 32:356

20. Pasqualini JR, Wiqvist N, Diczfalusy E 1966 Biosynthesis of aldosterone by human foetuses perfused with corticosterone at midterm. Biochim Biophys Acta 121:430

21. Robillard JE, Gomez RA, Meernik JG, Kuehl WD, VanOrden D 1982 Role of angiotensin II on the adrenal and vascular responses to hemorrhage during development in fetal lambs. Circ Res 50:645

22. Robillard JE, Gomez RA, VanOrden D, Smith FG, Jr. 1982 Comparison of the adrenal and renal responses to angiotensin II in fetal lambs and adult sheep. Circ Res 50:140

23. Robillard JE, Weitzman RE 1980 Developmental aspects of the fetal renal response to exogenous arginine vasopressin. Am J Physiol 238:F407

24. Robillard JE, Weitzman RE, Burmeister L, Smith FG, Jr 1981 Developmental aspects of the renal response to hypoxemia in the lamb fetus. Circ Res 48:128

25. Siegel SR 1981 Amniotic fluid concentrations of renin and aldosterone during development in the fetal sheep. Pediatr Res 15:1419

26. Siegel SR, Fisher DA 1980 . Ontogeny of the renin-angiotensin-aldosterone system in the fetal and newborn lamb. Pediatr Res 14.99

27. Siegel SR, Oakes G. Palmer 1981 Effects of angiotensin II on blood pressure, plasma renin activity, and aldosterone in fetal lambs. Dev Pharmacol Ther $3: 144$

28. Siegel SR, Oakes G, Palmer S 1981 Transplacental transfer of aldosterone and its effects on renal function in the fetal lamb. Pediatr Res 15:163

29. Wallenstein S, Zucker CL, Fleiss JL 1980 Some statistical methods useful in circulation research. Circ Res 47:1

30. Williams GH, Dluhy RG, Underwood RH 1970 The relationship of dietary potassium intake to the aldosterone stimulating properties of $\mathrm{ACTH}$. Clin Sci 39:489

31. Wintour EM, Barnes A, Cahill F, Hardy KJ, Horacek I, Scoggins BA 1979 Potassium: aldosterone relationship in pregnant ewes and chronically cannulated ovine fetuses. Pediatr Res 13:265

32. Wintour EM, Brown EH, Denton DA, Hardy KJ, McDougall JG, Oddie CJ Whipp GT 1975 The ontogeny and regulation of corticosteroid secretion by the ovine foetal adrenal. Acta Endocrinol 79:301

33. Wintour EM, Brown EH, Denton DA, Hardy $\mathrm{KJ}$, McDougall JG, Robinson PM, Rowe EJ, Whipp GT 1977 In vitro and in vivo adrenal cortical steroid production by fetal sheep: effect of angiotensin II, sodium deficiency and ACTH. In: Conti C (ed): Research on Steroids, Vol VII. Amsterdam, Elsevier/North-Holland, pp 475-485

34. Wintour EM, Coghlan JP, Hardy KJ, Lingwood BE, Rayner M, Scoggins BA 1980 Placental transfer of aldosterone in the sheep. J Endocrinol 86:305

35. This research was supported by United States Public Health Service Grants HD-1 1466 and HL-14388 and American Heart Association Grant 79-809. Jean E. Robillard is the recipient of Research Career Development Award HD-00254. Nancy A. Ayres is supported by Training Grant T-32-HL-0741304. R. Ariel Gomez is the recipient of National Kidney Foundation of Iowa Fellowship Award 15314. Kenneth T. Nakamura is the recipient of National Research Service Award 17429. Fred G. Smith, Jr. is the recipient of American Heart Association, lowa Affiliate, Grant 83-G-38.

36. Requests for reprints should be addressed to: Jean E. Robillard, M.D., Pediatric Nephrology Division, 225 Med Labs, University of lowa College of Medicine, lowa City, IA 52242

37. Received for publication July 18, 1983.

38. Accepted for publication August 2, 1983

\title{
Developmental Aspects of Renal $\beta$-Amino Acid Transport. IV. Brush Border Membrane Response to Altered Intake of Sulfur Amino Acids
}

\author{
RUSSELL W. CHESNEY, ${ }^{(41)}$ NAOMI GUSOWSKI, AND MARY THEISSEN \\ Pediatric Renal Disease Laboratory, Department of Pediatrics, University of Wisconsin, Center for Health \\ Sciences, Madison, Wisconsin, USA
}

\section{Summary}

Taurinuria is characteristic of the immature rat. The capacity of the kidney to accumulate the $\beta$-amino acid taurine and $D$ glucose was examined using isolated brush border membrane vesicles (BBMV) prepared from 28 -day-old rats. Taurine accumulation was inversely proportional to osmolarity, indicating uptake rather than binding, and taurine accumulation was $\mathrm{Na}^{+}-$ dependent. BBMV from 28-day rats did not accumulate D-glucose to the same degree as in adult BBMV, and the initial rate of uptake was slower. Taurine uptake had a similar $K_{m}$ and $V_{\text {max }}$ in BBMV from immature rats. Despite similarities in the kinetics of taurine uptake, higher urinary taurine concentrations are found in younger rats, suggesting that other factors, such as an efflux block, account for the taurinuria of young animals.

A diet low in methionine and taurine (LTD) given for 7 days resulted in a lower excretion and fractional excretion of taurine than in animals fed a normal sulfur amino acid diet (NTD). A high taurine diet (HTD) causes excessive taurinuria. These patterns of excretion are reflected at the brush border membrane surface with greater uptake after the LTD and reduced uptake after the HTD. A kinetic analysis of adult and 28-day-old animal BBMV reveals that the $V_{\max }$ of accumulation is altered by diet, whereas the $K_{m}$ remains unchanged. The $V_{\text {max }}$ is higher in BBMV from LTD animals and lower in BBMV from HTD animals. The kinetics of uptake are similar in adult and 28-day-old rat vesicles 